\title{
CRATONIC CONDITIONS BENEATH ARKHANGELSK, RUSSIA: GARNET PERIDOTITES FROM THE GRIB KIMBERLITE
}

\author{
Vladimir Malkovets ${ }^{1,2,3}$, Lawrence Taylor ${ }^{2}$, William Griffin ${ }^{3}$, Suzanne O'Reilly ${ }^{3}$, Norman \\ Pearson $^{3}$, Nikolai Pokhilenko ${ }^{1}$, Elisei Verichev ${ }^{4}$, Nikolai Golovin ${ }^{5}$, Konstantin Litasov ${ }^{6}$ \\ ${ }^{1}$ Institute of Mineralogy and Petrography SB RAS, Russia; ${ }^{2}$ Planetary Geoscience Institute, University of Tennessee, USA; \\ ${ }^{3}$ GEMOC National Key Centre, School of Earth Sciences, Macquarie University, Australia; ${ }^{4}$ Arkhangelskgeolrazvedka Ltd, \\ Russia; ${ }^{5}$ Arkhangelskgeoldobycha Ltd, Russia; 6 Institute of Mineralogy, Petrology and Economic Geology, Tohoku
} University, Japan;

\section{INTRODUCTION}

Kimberlite-derived xenoliths provide constraints on the composition, structure, and thermal state of the upper mantle underlying Archean cratons. The first kimberlite pipes were found in the Arkhangelsk kimberlite province in the early 1980's. Subsequently, 50 more pipes were discovered, 15 of them diamondiferous. Although the kimberlites in the Arkhangelsk kimberlite province were discovered decades ago, the mantle xenoliths found in these kimberlites have not received much attention. The main reason is that the well-known kimberlite pipes of Lomonosovo group are extremely altered. Xenoliths of the recently discovered, richly diamondiferous Grib kimberlite pipe have become the subject of special interest due to the abundance of fresh, large garnet and garnet-spinel lherzolite xenoliths. To date, there have been only preliminary petrological studies of mantle xenoliths of the Arkhangelsk kimberlite province (Sablukova, 1995; Sablukova et al., 1995; Verichev et al., 1998). The aim of this paper is to report on the first stage of our detailed studies of these xenoliths as they reveal knowledge of the nature of the lithosphere beneath the Verkhotina kimberlite field.

\section{GEOLOGY OF THE ARKHANGELSK REGION}

The East European Platform, a collage of Archaean cratons and Early Proterozoic mobile belts, underlies most of western Russia and the Baltic states. Riphean to Paleozoic sediments cover most of the platform to the south and east of Scandinavia. In its eastern part there are two Archean cratons, Kola and Karelis, separated by the Early Proterozoic Belomorian mobile belt.

The small-volume Arkhangelsk igneous activity is mostly in the form of sub-volcanic pipes (diatremes), together with some sills (Sinitsin \& Grib, 1995). Clusters of diatremes form several igneous fields (Fig.
1), each with distinctive petrological characteristics. The fields occur in two groups on the SE side of the White Sea: (1) along and up to $100 \mathrm{~km}$ inland from the Zimniy Bereg (i.e. Winter Coast); (2) on the NE side of the Onega Peninsula, separated from the Zimniy Bereg by the Gulf of Dvina.

A short intense, widespread phase of Late Devonian $(\sim 380-360 \quad$ Ma $)$ mafic, alkaline-ultramafic and carbonatitic magmatism immediately followed largescale lithospheric doming of the East European

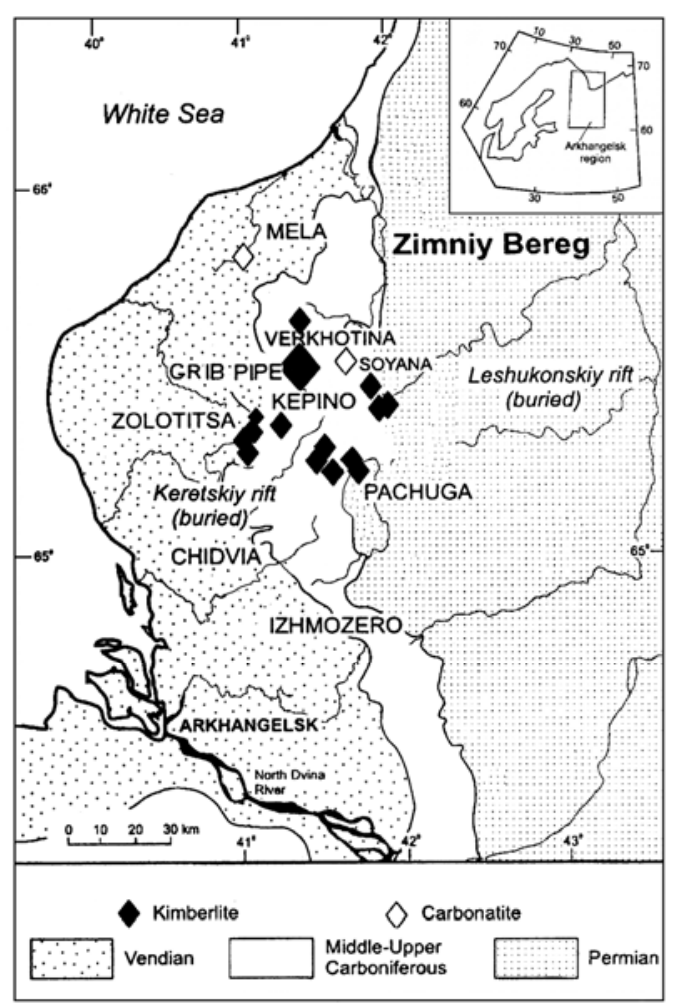

Figure 1: Simplified geological sketch map of the Arkhangelsk Alkaline Igneous Province (Mahotkin et al., 2000). 
Platform (Mahotkin et al., 2000). The Late Devonian magmatism of the Kola region forms one of the world's largest intrusive and sub-volcanic alkaline provinces.

The Kola Alkaline Province outcrops over an area of $\sim 100000 \mathrm{~km}^{2}$ and comprises 24 igneous complexes (Kogarko et al., 1995; Mahotkin et al., 2000).

Kimberlites are the predominant rock-type in the Zolotitsa and Mela fields, and a component of the Kepino-Pachuga and Verkhotina-Soyana fields. They can be divided geographically (Fig. 1) into a predominantly mica-poor Eastern Group and a predominantly micaceous Western Group, superficially similar to Group I and Group II South African kimberlites, respectively (Parsadanyan et al., 1996). The discovery in 1996 of the richly diamondiferous Grib kimberlite pipe (also known as Anomaly 441) has terminated the long-established notion (e.g., Sablukova et al., 1995) that only the Western Group kimberlites are potentially valuable economically (Verichev et al., 1998).

\section{XENOLITH PETROGRAHY}

A suite of approximately 90 mantle xenoliths was obtained from the Grib pipe. Most are $<10 \mathrm{~cm}$ in diameter, with a few as large as $20 \mathrm{~cm}$. This suite of mantle xenoliths encompasses garnet peridotites, pyroxenites, and eclogites. The present study addresses the detailed mineralogy and geochemistry of a selected sampling of 16 garnet peridotites. The peridotite set includes 13 garnet lherzolites and 3 garnet harzburgites. Megacrysts (commonly $<5 \mathrm{~cm}$ in size) are also abundant in the Grib pipe. Pyrope, chrome-diopside, and picroilmenite are most abundant, and phlogopite, olivine, and orthopyroxene occur in minor accounts, along with traces of chrome spinel. Megacrysts of single crystals of chrome-diopside are rare; most diopside megacrysts are polycrystalline intergrowths and/or contain smaller grains of minerals from the megacrystal assemblage.

All xenoliths possess a protogranular texture, with no sheared peridotites in the suite. Xenoliths of coarse peridotite are composed of olivine (55-90\%), with lesser amounts of clinopyroxene (0-12\%), orthopyroxene $(3-15 \%)$, garnet $(2-7 \%)$, and spinel ( 0 $1 \%$ ). Three of the garnet lherzolites and two of the garnet harzburgites contain phlogopite, in apparent textural equilibrium with the other primary minerals. The predominant rock types are lherzolite and harzburgite. The garnet lherzolites all contain high modal abundances of clinopyroxene and garnet.
Secondary alteration has produced the development of serpentine replacing olivine and orthopyroxene.

\section{MINERALOGICAL AND GEOCHEMICAL CHARACTERISTICS}

\section{MAJOR ELEMENTS}

Olivine compositions range in $\mathrm{Mg \#}$ from 90.8 to 93 (Table 1). The most magnesian olivine ( $\mathrm{Fo}_{92-93}$ ) occurs in spinel-garnet and garnet lherzolites and in harzburgites. Olivines from phlogopite-bearing peridotites have lower $\mathrm{Mg \#}$ and range from 90.8 to 92.1. Concentrations of $\mathrm{Ni}$ in olivine range from 0.33 to $0.42 \mathrm{wt} \%$.

\section{Table 1: Composition of olivines}

\begin{tabular}{|c|c|c|c|c|}
\hline Sample & $110 / 417$ & $89 / 305$ & $90 / 395$ & 216 \\
\hline Rock & Lher & Phl Lher & Harz & Phl Harz \\
\hline $\mathrm{SiO}_{2}$ & 41.2 & 40.6 & 40.8 & 41.8 \\
\hline $\mathrm{TiO}_{2}$ & 0.01 & 0.01 & 0.01 & 0.01 \\
\hline $\mathrm{Al}_{2} \mathrm{O}_{3}$ & 0.02 & 0.01 & 0.01 & 0.01 \\
\hline $\mathrm{Cr}_{2} \mathrm{O}_{3}$ & 0.01 & 0.01 & 0.03 & 0.04 \\
\hline $\mathrm{FeO}$ & 8.11 & 8.97 & 7.71 & 7.68 \\
\hline $\mathrm{MnO}$ & 0.08 & 0.11 & 0.11 & 0.11 \\
\hline $\mathrm{MgO}$ & 50.9 & 49.9 & 51.4 & 50.6 \\
\hline $\mathrm{CaO}$ & 0.01 & 0.01 & 0.01 & 0.04 \\
\hline $\mathrm{Na}_{2} \mathrm{O}$ & 0.04 & 0.01 & 0.02 & 0.01 \\
\hline $\mathrm{NiO}$ & 0.36 & 0.33 & 0.41 & 0.41 \\
\hline Mg\# & 91.8 & 90.8 & 92.2 & 92.1 \\
\hline Total & 100.7 & 99.92 & 100.5 & 100.7 \\
\hline
\end{tabular}

Table 2: Composition of orthopyroxenes

$\begin{array}{lllll}\begin{array}{l}\text { Sample } \\ \text { Rock }\end{array} & \begin{array}{l}\text { 110/417 } \\ \text { Lher }\end{array} & \begin{array}{l}\text { 89/305 } \\ \text { Phl Lher Harz }\end{array} & \begin{array}{l}\text { 90/395 } \\ \text { Phl Harz }\end{array} \\ \mathrm{SiO}_{2} & 58.3 & 57.5 & 57.6 & 58.6 \\ \mathrm{TiO}_{2} & 0.01 & 0.19 & 0.01 & 0.05 \\ \mathrm{Al}_{2} \mathrm{O}_{3} & 0.57 & 0.35 & 0.69 & 0.75 \\ \mathrm{Cr}_{2} \mathrm{O}_{3} & 0.29 & 0.81 & 0.18 & 0.19 \\ \mathrm{FeO} & 4.87 & 6.49 & 4.96 & 4.81 \\ \mathrm{MnO} & 0.19 & 0.18 & 0.13 & 0.14 \\ \mathrm{MgO} & 36.3 & 33.4 & 36.2 & 35.8 \\ \mathrm{CaO} & 0.28 & 1.01 & 0.18 & 0.16 \\ \mathrm{Na} O & 0.05 & 0.13 & 0.02 & 0.06 \\ \mathrm{NiO} & 0.17 & 0.16 & 0.11 & 0.08 \\ \mathrm{Mg} \# & 93.0 & 90.1 & 92.8 & 93.0 \\ \text { Total } & 101 & 100.1 & 100.1 & 100.7\end{array}$


With the exception of one unusual sample (89/305), orthopyroxene compositions vary little within and between xenoliths types ( $\mathrm{MG} \#=92.3-94.2$; Table 2 ). In all cases, orthopyroxene is slightly more $\mathrm{Mg}$-rich than the coexisting olivine, an indication of equilibrium (Gurney et al., 1979). Orthopyroxene compositions from different rock types are quite uniform in terms of their $\mathrm{Cr}_{2} \mathrm{O}_{3}$ and $\mathrm{CaO}$ contents. Only orthopyroxene from a unique, probably deep-seated phlogopite spinel/garnet lherzolite (89/305) has low Mg\# (90.15), $\mathrm{Al}_{2} \mathrm{O}_{3}$, and high $\mathrm{TiO}_{2}, \mathrm{Cr}_{2} \mathrm{O}_{3}, \mathrm{CaO}$, and $\mathrm{Na}_{2} \mathrm{O}$ (Table 2). Orthopyroxene grains are homogeneous, especially for $\mathrm{Al}_{2} \mathrm{O}_{3}$ and $\mathrm{CaO}$.

Clinopyroxene in peridotite has high- $\mathrm{Cr}$ content (1.22.6 wt $\% \quad \mathrm{Cr}_{2} \mathrm{O}_{3}$ ) and is classified as $\mathrm{Cr}$-diopside. Clinopyroxene compositions range in $\mathrm{Mg} \#$ from 90.3 to 95.5 (Table 3). Clinopyroxene compositions are constant. Clinopyroxene from the unusual phlogopite spinel/garnet lherzolite $(89 / 305)$ has intermediate $\mathrm{Mg \#}$ (92.8), $\mathrm{Cr}_{2} \mathrm{O}_{3}$, and the highest $\mathrm{TiO}_{2}, \mathrm{Al}_{2} \mathrm{O}_{3}$, and $\mathrm{Na}_{2} \mathrm{O}$ (Table 3).

\section{Table 3: Composition of clinopyroxenes}

\begin{tabular}{|c|c|c|c|c|}
\hline Sample & $110 / 417$ & $89 / 305$ & $53 / 501$ & $93 / 236$ \\
\hline Rock & Lher & Phl Lher & Lher & Lher \\
\hline $\mathrm{SiO}_{2}$ & 54.6 & 54.9 & 54.78 & 55.3 \\
\hline $\mathrm{TiO}_{2}$ & 0.25 & 0.27 & 0.21 & 0.16 \\
\hline $\mathrm{Al}_{2} \mathrm{O}_{3}$ & 1.82 & 3.98 & 2.92 & 3.03 \\
\hline $\mathrm{Cr}_{2} \mathrm{O}_{3}$ & 2.23 & 1.59 & 1.51 & 2.63 \\
\hline $\mathrm{FeO}$ & 3.06 & 1.98 & 1.57 & 1.51 \\
\hline $\mathrm{MnO}$ & 0.11 & 0.05 & 0.08 & 0.05 \\
\hline $\mathrm{MgO}$ & 16.1 & 14.4 & 15.4 & 14.9 \\
\hline $\mathrm{CaO}$ & 19.1 & 19.7 & 20.9 & 19.7 \\
\hline $\mathrm{Na}_{2} \mathrm{O}$ & 2.51 & 3.09 & 2.26 & 2.85 \\
\hline $\mathrm{NiO}$ & 0.01 & 0.01 & 0.01 & 0.02 \\
\hline Mg\# & 90.33 & 92.8 & 94.6 & 94.6 \\
\hline Total & 99.71 & 100.1 & 99.7 & 100.1 \\
\hline
\end{tabular}

Garnet in Grib peridotites contains high $\mathrm{MgO}$, low $\mathrm{CaO}$, and moderate $\mathrm{Cr}_{2} \mathrm{O}_{3}$, typical of pyrope. On the plot of $\mathrm{Cr}_{2} \mathrm{O}_{3}$ versus $\mathrm{CaO}$, the pyrope compositions define a common 'lherzolitic' trend (Sobolev et al., 1973; Fig. 2). However, some of the garnet-bearing samples are, in fact, harzburgites. Concentrations of $\mathrm{Ti}$ in garnet ranges from 0.01 to $0.19 \mathrm{wt} \%$, with the highest value $0.22 \mathrm{wt} \%$ in sample $89 / 305$. Spinel in Grib peridotites can be divided into two groups. The first one is typical of chromite of peridotites with low $\mathrm{TiO}_{2}$. Spinel from the second group has high $\mathrm{TiO}_{2}$, $\mathrm{FeO}$, and low $\mathrm{Al}_{2} \mathrm{O}_{3}$ and occurs in phlogopite-bearing lherzolites (Table 4).

\section{Table 4: Composition of garnets and chromites}

\begin{tabular}{|c|c|c|c|c|}
\hline Sample & $110 / 417$ & $89 / 305$ & 216 & $89 / 305$ \\
\hline Rock & Lher & Phl Lher & Phl Harz & Phl Lher \\
\hline Mineral & Gar & Gar & Chr & Chr \\
\hline $\mathrm{SiO}_{2}$ & 41.72 & 41.8 & 0.04 & 0.07 \\
\hline $\mathrm{TiO}_{2}$ & 0.01 & 0.22 & 0.87 & 3.29 \\
\hline $\mathrm{Al}_{2} \mathrm{O}_{3}$ & 19.7 & 22.2 & 14.8 & 6.59 \\
\hline $\mathrm{Cr}_{2} \mathrm{O}_{3}$ & 5.37 & 1.91 & 50.4 & 51.3 \\
\hline $\mathrm{FeO}$ & 8.64 & 9.67 & 19.1 & 25.1 \\
\hline $\mathrm{MnO}$ & 0.36 & 0.52 & 0.01 & 0.01 \\
\hline $\mathrm{MgO}$ & 19.4 & 19.4 & 11.7 & 11.4 \\
\hline $\mathrm{CaO}$ & 5.69 & 4.31 & 0 & 0 \\
\hline $\mathrm{Na}_{2} \mathrm{O}$ & 0.01 & 0.06 & 0 & 0 \\
\hline Total & 100.8 & 100.1 & 97.1 & 97.9 \\
\hline
\end{tabular}

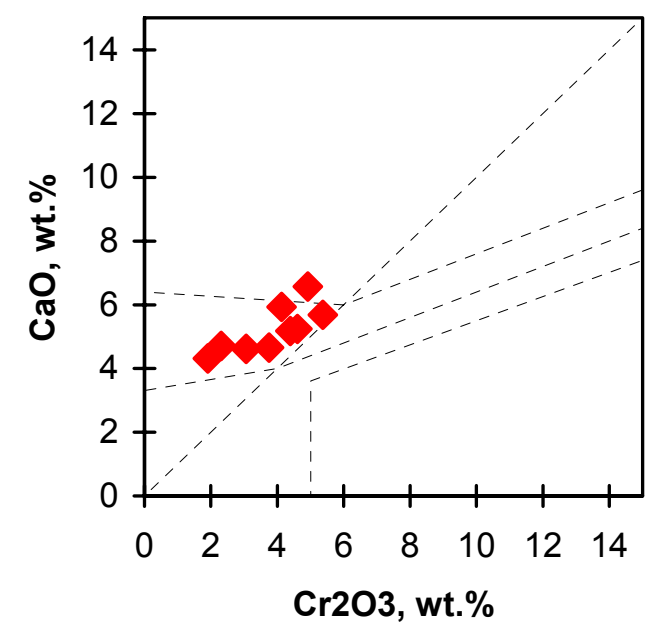

Figure 2: $\mathrm{Cr}_{2} \mathrm{O}_{3}$ vs $\mathrm{CaO}$ plot for garnet in Grib peridotites. Fields shown for garnets are from Sobolev et al., (1973).

\section{P-T Estimation}

Garnet and orthopyroxene are relatively homogeneous, thereby implying equilibrium between these two phases. Hence, the compositions of these coexisting phases have been used for geothermobarometry estimates of the P-T conditions that existed beneath this Middle Paleozoic craton. Estimates of the pressures and temperatures are based on a combination of the Opx-thermometer of Brey and Kohler (1990) and the barometer of McGregor (1974), as well as the thermometer of Finnerty and Boyd (1984) and the 
barometer of McGregor (1974). Temperatures and pressures range from 31 to $62 \mathrm{kbar}$ at $780-1300{ }^{\circ} \mathrm{C}$ and 20 to $62 \mathrm{kbar}$ at $600-1100{ }^{\circ} \mathrm{C}$, for these two schemes for $\mathrm{P}-\mathrm{T}$ estimation. These P-T estimates define a geotherm with a relatively low heat flow of about $37-38 \mathrm{mv} / \mathrm{m} 2$.

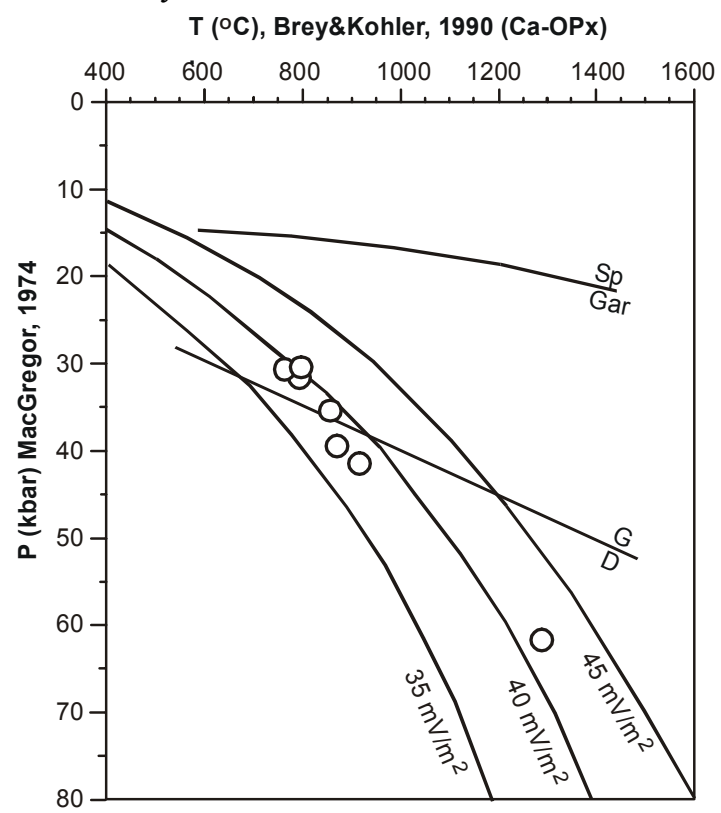

Figure 3: Equilibrium P-T estimates for the Grib peridotites according to MacGregor (1974) and Brey\&Kohler (1990).

\section{TRACE ELEMENTS}

Trace-element analyses of garnet, clinopyroxene, and phlogopite were made in-situ in polished thick sections, with LA-ICP-MS at Macquarie University, Australia. Methods and operating conditions have been described by Norman et al., 1996. REE patterns for lherzolitic clinopyroxene vary from primitive to weakly depleted. Chondrite-normalized ratios of $\mathrm{La} / \mathrm{Sm}$ measure the slopes of the LREEs and range from 0.37 to 0.82 ; $\mathrm{La} / \mathrm{Yb}$ represents the general slope of the entire $\mathrm{REE}$ pattern and ranges from 8.57 to 28.8 ; the $\mathrm{Gd} / \mathrm{Yb}$ ratios relate to the slopes of the HREEs and vary from 0.45 to 0.48. Harzburgitic garnets are depleted in both the LREEs and MREEs and the $\mathrm{Gd} / \mathrm{Yb}$ ratios vary from 0.1 to 0.25 .

\section{RE/Os SULFIDE DATING}

The mineralogy and geochemistry of interstitial sulfide minerals and sulfide inclusions in minerals were carefully studied in the garnet lherzolites and harzburgites. In garnet harzburgite \#53/292, a highly unusual homogeneous grain of interstitial Fe-Ni sulfide was found having anomalously high contents of $\mathrm{Co}$, Os, and Pt. This sulfide grain was dated in-situ by Re/Os isotope analysis, by LA-MC-ICP-MS. The Re/Os model age is 2.9-3.1 Ga. Such an ancient age for the continental lithospheric mantle of the Arkhangelsk diamondiferous province is in good agreement with ages detected for the continental lithospheric mantle beneath Yakutia and southern Africa (Pearson et al., 1995a, b).

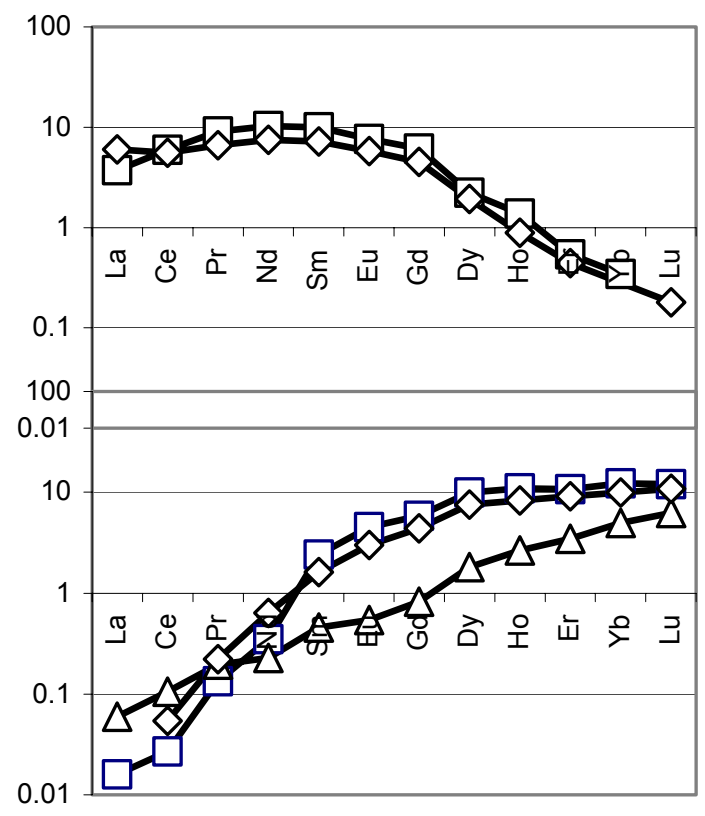

Figure 4: REE patterns of clinopyroxenes (top) and garnets (bottom) in the Grib peridotites.

\section{CONCLUSIONS}

(i) The mantle beneath the Verkhotina kimberlite field shows many features common to cratonic mantle elsewhere. The Grib pipe kimberlite contains a xenolith suite comprising mantle-derived peridotite and eclogite xenoliths (see Malkovets et al., this volume)

(ii) The peridotite xenoliths encompass a range of rock types, including garnet lherzolites, garnet garzburgites, garnet websterites, and dunites. Variations in modes and mineral compositions indicate gradations between these different rock types.

(iii) $\mathrm{P}-\mathrm{T}$ estimates for the peridotite xenoliths produce a well-defined paleogeotherm below $1000{ }^{\circ} \mathrm{C}$, with a defined low heatflow of about $37-38 \mathrm{mw} / \mathrm{m}^{2}$, whereas at 
higher $\mathrm{T}$ the geotherm is closer to a value of $42 \mathrm{mw} / \mathrm{m}^{2}$.

(iv) The Re/Os model age of a single sulfide grain yielded 2.9-3.1 Ga. Such an ancient age for the continental lithospheric mantle of the Arkhangelsk diamondiferous province is in good agreement with ages detected for the continental lithospheric mantle beneath Yakutia and southern Africa.

\section{REFERENCES}

Brey, G.P., Kohler, T., 1990. Geothermobarometry in fourphase lherzolites. II. New thermobarometers, and practical assessment of existing thermobarometers. Jour. Petrol. 31, 1353-1378.

Gurney, J.J., Harris, J.W., Rickard, R.S., 1979. Silicate and oxide inclusions in diamonds from the Finsch kimberlite pipe. In: Boyd, F.R., Meyer, H.O.A. (Eds.), Kimberlites, Diatremes and Diamonds: their Geology and Petrology and Geochemistry. Washington, DC: American Geophysical Union, pp. 1-15.

Kogarko, L.N., Kononova, V.A., Orlova, M.P., Woolley. A.P., 1995. Alkaline Rocks and Carbonatites of the World: Part 2: Former USSR. Chapman\&Hall, London.

MacGregor, I.D., 1974. The system $\mathrm{MgO}-\mathrm{Al}_{2} \mathrm{O}_{3}-\mathrm{SiO}_{2}$ : solubility of $\mathrm{Al}_{2} \mathrm{O}_{3}$ in enstatite for spinel and garnet peridotite compositions. Amer. Mineral. 59, 110-119.

Mahotkin, I.L., Gibson, S.A., Thompson, R.N., Zhuravlev, D.Z., Zherdev P.U., 2000. Late Devonian diamondiferous kimberlite and alkaline picrite (protokimberlite?) magmatism in the Arkhangelsk region, NW Russia. Jour. of Petrol. 41, 201-227.

Norman, M.D., Pearson, N.J., Sharma, A.,Griffin, W.L., 1996. Quantitative analysis of trace elements in geological materials by laser ablation ICPMS: instrumental operating conditions and calibration values of NIST glasses. Geostand Newsl 20, 247-261.

Parsadanyan, K.S., Kononova, V.A., Bogatikov, O.A., 1996. Sources of heterogeneous magmatism of the Arkhangelsk diamondiferous province. Petrology. 4, 460-479.

Pearson, D.G., Shirey, S.B., Carlson, R.W., Boyd, F.R., Pokhilenko, N.P., Shimizu, N, 1995a. Re-Os, Sm-Nd \& $\mathrm{Rb}-\mathrm{Sr}$ isotope evidence for thick Archaean lithospheric mantle beneath the Siberia craton modified by multi-stage metasomatism. Geochim. Cosmochim. Acta. 59, 959-977.

Pearson, D.G., Carlson, R.W., Shirey, S.B., Boyd, F.R., Nixon, P.H., 1995b. The stabilisation of Archaean lithospheric mantle: A Re-Os isotope study of peridotite xenoliths from the Kaapvaal craton. Earth Planet. Sci. Lett. 134, 341-357.
Sablukova, L.I., 1995. Mantle nodules in kimberlite rocks of Arkhangelsk. Ext. Abstr. $6^{\text {th }}$ Int. Kimb. Conf. Novosibirsk, Russia, pp. 484-486.

Sablukova, L.I., Sablukov, S., Griffin. W.L., O’Reilly, S.Y., Ryan, C.G., Win, T.T., Grib, V., 1995. Lithosphere evolution in the Arkhangelsk kimberlite province. Ext. Abstr. $6^{\text {th }}$ Int. Kimb. Conf. Novosibirsk, Russia, pp. 487-489.

Sinitsin, A.V., Grib, V.P., 1995. Arkhangelsk kimberlite province: field guidebook. $6^{\text {th }}$ Int. Kimb. Conf. Novosibirsk, Russia.

Sobolev, N.V., Lavrent'ev, Yu.G., Pokhilenko, N.P., Usova, L.P., 1973. Chrome-rich garnets from the kimberlites of Yakutia and their parageneses. Contrib. Miner. Petrol. 40, 39-52.

Verichev, E.M., Sablukov, S.M., Sablukova, L.I., Zhuravlev, D.Z., 1998. A new type of diamondiferous kimberlite of the Zimniy Bereg area (pipe named after Vladimir Grib). Ext. Abstr. $7^{\text {th }}$ Int. Kimb. Conf. Cape Town, South Africa, pp. 940-942.

Contact: Vlad Malkovets, Planetary Geosciences Institute, Department of Earth and Planetary Sciences, University of Tennessee, Knoxville, TN, 37996-1410, USA, E-mail: vomal@uiggm.nsc.ru 